\title{
Correction to: Developmental programming of offspring adipose tissue biology and obesity risk
}

\author{
Amanda Rodgers - Amanda N. Sferruzzi-Perri (iD
}

Published online: 10 May 2021

(c) Crown 2021. This article is published with open access

Correction to: International Journal of Obesity

https://doi.org/10.1038/s41366-021-00790-w

The original version of this article unfortunately contained a mistake. There were typographical errors in Fig. 2A (the birthweight of the mouse should be $1-2 \mathrm{~g}$ and for the pig it should be $1400 \mathrm{~g}$ ). The correct values are given in the figure below. The authors apologize for the error. The original article has been corrected.

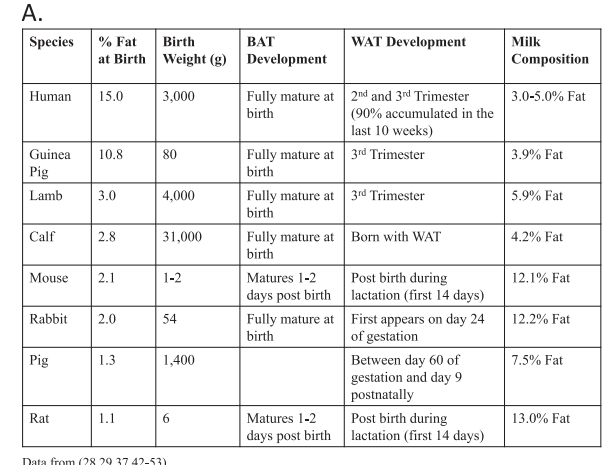

Open Access This article is licensed under a Creative Commons Attribution 4.0 International License, which permits use, sharing, adaptation, distribution and reproduction in any medium or format, as long as you give appropriate credit to the original author(s) and the source, provide a link to the Creative Commons license, and indicate if changes were made. The images or other third party material in this article are included in the article's Creative Commons license, unless indicated otherwise in a credit line to the material. If material is not included in the article's Creative Commons license and your intended use is not permitted by statutory regulation or exceeds the permitted use, you will need to obtain permission directly from the copyright holder. To view a copy of this license, visit http://creativecommons. org/licenses/by/4.0/. 